\title{
PENDUGAAN UMUR SIMPAN GULA KELAPA KRISTAL MENGGUNAKAN METODE AKSELERASI BERDASARKAN PENDEKATAN KADAR AIR KRITIS
}

\section{Accelerated Self-life Testing of Crystal Coconut Sugar Using a Critical Moisture Content Approach}

\author{
Abdul Mukhlis Ritonga*, Masrukhi, Siswantoro \\ Program Studi Teknik Pertanian - Fakultas Pertanian - Universitas Jenderal Soedirman \\ Jl. Prof.Dr.HR. Boenyamin - Banyumas 53122 \\ *Penulis Korespondensi, e-mail : mukhlis.abdul@yahoo.com
}

Disubmit: 23 Oktober 2018 Direvisi: 14 Februari 2020 Diterima: 27 Februari 2020

\begin{abstract}
ABSTRAK
Keterangan umur simpan (masa kadaluarsa) produk pangan merupakan salah satu informasi yang wajib dicantumkan oleh produsen pada label kemasan produk pangan. Penentuan umur simpan produk pangan dapat dilakukan dengan menyimpan produk pada kondisi penyimpanan yang sebenarnya. Cara ini menghasilkan hasil yang paling tepat, namun memerlukan waktu yang lama dan biaya yang besar. Metode pendugaan umur simpan dapat dilakukan dengan metode Accelerated Shelf-life Testing (ASLT), yaitu dengan cara menyimpan produk pangan pada lingkungan yang menyebabkannya cepat rusak, baik pada kondisi suhu atau kelembaban ruang penyimpanan yang lebih tinggi. Tujuan dari penelitian ini adalah (1) untuk menduga umur simpan gula kelapa kristal dengan dua jenis bahan kemasan yang berbeda dan menggunakan metode ASLT (Accelerated Shelf Life Testing) (2) untuk memberikan jaminan mutu mengenai keamanan gula merah. Variabel yang diamati pada penelitian ini meliputi : kadar air awal produk (Mo, g $\mathrm{H}_{2} \mathrm{O} / \mathrm{g}$ padatan), kadar air kesetimbangan produk ( $\mathrm{Me}, \mathrm{g} \mathrm{H}_{2} \mathrm{O} / \mathrm{g}$ padatan), kemiringan/slope kurva sorpsi isotermis (b), kadar air kritis (Mc, g $\mathrm{H}_{2} \mathrm{O} / \mathrm{g}$ padatan), konstanta permeabilitas uap air kemasan $\left(\mathrm{k} / \mathrm{x}, \mathrm{g} / \mathrm{m}^{2}\right.$.hari.mmHg), luas permukaan kemasan $\left(\mathrm{A}, \mathrm{m}^{2}\right)$, berat kering produk dalam kemasan (Ws, g padatan), tekanan uap air jenuh (Po,mmHg). Hasil penelitian menunjukkan bahwa umur simpan gula kelapa kirstal yang dikemas menggunakan alumnium foil yang disimpan pada RH $60 \%$ adalah 11 bulan, sedangkan yang dikemas dengan Plastik PE adalah 18 bulan.
\end{abstract}

Kata Kunci : Kadar air, Kemasan, Metode ASLT, Alumanium Foil, Polietilen

\section{ABSTRACT}

Information on shelf-life (expiration period) of food products is one of the information that must be included by producers on food product packaging labels. Determining the shelf life of food products can be done by storing the product in actual storage conditions. This method produces the most appropriate results, but requires a long time and a large cost. Estimating method of shelf life can be done using the Accelerated Shelf-life Testing (ASLT) method, which is by storing food products in an environment that causes them to break down quickly, both at higher temperature or humidity conditions. The purpose of this study are (1) to estimate the shelf life of crystal coconut sugar with two different types of packaging materials and use the Accelerated Shelf Life Testing method (ASLT), (2) to provide quality assurance regarding the safety of brown sugar. The variables observed in this study are: the initial moisture content of the product (Mo, $g$ $\mathrm{H} 2 \mathrm{O} / \mathrm{g}$ solids), the product equilibrium moisture content ( $\mathrm{Me}, \mathrm{g} \mathrm{H}_{2} \mathrm{O} / \mathrm{g}$ solids), slope/slope of the isothermic sorption curve (b), critical water content ( $M c, g \mathrm{H}_{2} \mathrm{O} / g$ solids), vapor permeability constant of bottled wate $(\mathrm{k} / \mathrm{x}, \mathrm{g} / \mathrm{m} 2$.day.mmHg), area packaging surface $(A, m 2)$, dry weight of packaged products (Ws, $g$ solids), saturated water vapor pressure $(\mathrm{Po}, \mathrm{mmHg})$. The results showed crystal coconut sugar using aluminum foil 
Jurnal Teknologi Pertanian Vol. 21 No. 1 [April 2020] 11-18

Pendugaan Umur Simpan Gula Kelapa Kristal Menggunakan Metode Akselerasi [Ritonga dkk]

packaging and stored at RH $60 \%$ had shelf life of 11 moths and crystal coconut sugar using polyethylene packaging had shelf life of 18 months.

Keywords: Moisture Content, Packaging, ASLT Method, Aluminum Foil, Polyethylene

\section{PENDAHULUAN}

Umur simpan secara umum mengandung pengertian rentang waktu antara saat produk mulai dikemas atau diproduksi dengan saat mulai digunakan dengan mutu produk masih memenuhi syarat dikonsumsi (Hine, 1987). Metode Accelerated Shelf Life Testing (ASLT) merupakan metode penentuan umur simpan produk pangan menggunakan suatu kondisi lingkungan yang dapat mempercepat terjadinya reaksi-reaksi penurunan mutu produk pangan (Arpah dan Syarief, 2000). Metode akselerasi dapat dilakukan dalam waktu relatif singkat pada kondisi ekstrim namun tetap memiliki ketepatan dan akurasi yang tepat (Arpah, 2001). Penerapan metode akselerasi perlu memperhatikan karakteristik dan penyebab kerusakan produk yang akan ditentukan umur simpannya. Metode akselerasi dapat dilakukan dengan pendekatan model arrhenius dan model kadar air kritis. Model arrhenius biasanya digunakan untuk produk yang sensitif terhadap perubahan suhu penyimpanan, sedangkan model kadar air kritis biasanya digunakan untuk produk yang mudah rusak karena penyerapan air oleh produk. Gula kelapa kristal merupakan produk yang diduga mempunyai umur simpan yang pendek. Kadar air dan akitifitas air yang tinggi akan menyebabkan gula kelapa kristal kering dan susah dipisahkan. Kadar air gula semut yang tinggi akan memicu terjadinya penggumpalan gula (clumping), hal ini juga akan mengurangi kualitas fisik produk. Sehingga diantara model untuk menduga umur simpan produk pangan secara cepat adalah dengan pendekatan kadar air kritis.

Kerusakan produk pangan dapat disebabkan oleh adanya penyerapan air oleh produk selama penyimpanan. Kerusakan produk dapat diamati dari penurunan kekerasan atau kerenyahan, dan/atau peningkatan kekeringan atau penggumpalan. Laju penyerapan air oleh produk pangan selama penyimpanan dipengaruhi oleh tekanan uap air murni pada suhu udara tertentu, permea- bilitas uap air dan luasan kemasan yang digunakan, kadar air awal produk, berat kering awal produk, kadar air kritis, kadar air kesetimbangan pada RH penyimpanan, dan slope kurva isoterm sorpsi air, faktor-faktor tersebut diformulasikan oleh Labuza dan Schmidl (1985) menjadi model matematika dan digunakan sebagai model untuk menduga umur simpan. Persamaan untuk menentukan umur simpan dinyatakan dengan persamaan (1) (Bell dan Labuza, 2000).

$t($ hari $)=\frac{i n \frac{(M e-M o)}{(M e-M c)}}{\frac{k}{x}\left(\frac{A}{W s}\right) \frac{P o}{b}}$

Keterangan:

$\mathrm{T}$ : umur simpan (hari)

Me : kadar air kesetimbangan produk ( $\mathrm{g} \mathrm{H}_{2} \mathrm{O} / \mathrm{g}$ padatan)

Mo : kadar air awal produk ( $\mathrm{g} \mathrm{H}_{2} \mathrm{O} / \mathrm{g}$ padatan)

Mc : kadar air kritis produk ( $\mathrm{g} \mathrm{H}_{2} \mathrm{O} /$ g padatan)

$\mathrm{k} / \mathrm{x}$ : konstanta permeabilitas uap air kemasan $\left(\mathrm{g} / \mathrm{m}^{2}\right.$.hari.mmHg)

A : luas permukaan kemasan $\left(\mathrm{m}^{2}\right)$

Ws : bobot padatan per kemasan (g)

Po : tekanan uap jenuh $(\mathrm{mmHg})$

B : kemiringan kurva sorpsi isotermis

Tujuan dari penelitian ini yaitu untuk menduga umur simpan gula kelapa kristal dengan menggunakan dua jenis kemasan yang berbeda dan menggunakan metode akselerasi dengan pendekatan kadar air kritis.

\section{METODE}

Bahan yang digunakan pada penelitian ini adalah produk gula kelapa kristal yang dikemas dengan menggunakan dua jenis kemasan yaitu PE (Polietilen) dan Alumuniumfoil. Sedangkan bahan kimia yang digunakan untuk percobaan kurva isoterm sorpsi air adalah larutan garam jenuh yang telah diukur nilai $\mathrm{AW}$ nya $\left(\mathrm{K}_{2} \mathrm{CO}_{3}, \mathrm{NaCl}, \mathrm{KCl}\right.$, $\mathrm{Mgcl}_{2}$, dan $\mathrm{KNO}_{3}$ ), silica gel, dan akuades 
Alat-alat yang digunakan dalam penelitian ini antara lain: oven, desikator kecil, Coloreader, neraca analitik, pencapit logam, peralatan gelas, cawan, alumunium foil, $\mathrm{PE}$ (polietilen), dan hygrometer.

Variabel yang diukur pada penelitian ini adalah:

\section{Pengukuran Kadar Air Awal (Mo)}

Kadar air gula kelapa kristal sebelum disimpan diukur dengan metode oven (AOAC, 1995). Kadar air awal (Mo) dinyatakan sebagai $\mathrm{gH}_{2} \mathrm{O} / \mathrm{g}$ padatan.

$\mathrm{Ka} \mathrm{Mo}=\frac{(W 1+W 2)-W 3}{(W 3-W 1)} \mathrm{g} \mathrm{H}_{2} \mathrm{O} / \mathrm{g}$ solid

Keterangan :

$\mathrm{W}_{1}$ : Berat cawan kosong (g)

$\mathrm{W}_{2}$ : Berat sampel awal (g)

$\mathrm{W}_{3}=$ Berat(sampel+cawan) setelahdikeringkan $(\mathrm{g})$

\section{Pengukuran Kadar Air Kritis (Mc)}

Kadar air kritis (Mc) adalah nilai kadar air kritis pada kondisi dimana produk pangan mulai tidak diterima oleh konsumen secara organoleptic. Penentuan kadar air kritis dilakukan dengan cara penyimpan terlebih dahulu gula kelapa kristal pada suhu kamar $\left(30^{\circ} \mathrm{C}\right)$ di ruangan terbuka tanpa kemasan $(\mathrm{RH}$ $60-70 \%$ ). Selama periode penyimpanan tersebut, dilakukan uji sensori oleh panelis semi terlatih (15 orang) setiap 24 jam. Pengujian dilakukan hingga dapat ditentukan saat tekstur kering pada gula mulai hilang. Pengujian dilakukan dengan cara mengambil sedikit bagian dari gula kelapa kristal kemudian diremas menggunakan ibu jari dan telunjuk untuk mengetahui apakah gula bertekstur keras atau lembek. Skala penilaian berkisar antara 1-7, dimana skor 1 menunjukan skala sangat tidak kering dan skor 7 skala sangat kering. Pada setiap periode pengujian sensori dilakukan pengukuran kadar air dengan metode oven (Sudarmadji et al., 1997).

Data kadar air dan nilai kekeringan secara obyektif untuk masing- masing sampel pada setiap periode pengamatan diplotkan dengan skor kekeringan yang bersesuaian, sehingga diperoleh grafik hubungan antara skor kekeringan dengan kadar air. Berdasarkan regresi linear yang diperoleh maka kadar air kritis dihitung pada saat skor kekeringan panelis bernilai 3 (skala agak tidak kering).
Kadar air kritis dinyatakan dalam $\mathrm{g} \mathrm{H}_{2} \mathrm{O} / \mathrm{g}$ padatan.

\section{Kadar Air Kesetimbangan (Me)}

Pembuatan kurva isoterm sorpsi air gula kelapa kristal diawali dengan membuat larutan garam jenuh yang digunakan untuk mengatur kelembaban relatof $(\mathrm{RH})$ desikator. Garam yang digunakan adalah $\mathrm{MgCl}_{2}, \mathrm{~K}_{2} \mathrm{CO}_{3}$, $\mathrm{NaCl}, \mathrm{KCl}$, dan $\mathrm{KNO}_{3}$ yang memberikan nilai aktivitas air hasil pengukuran sebesar 0,324 0,923 atau RH berkisar 32,4-92,3\%.

Tabel 1. Nilai aktivitas air untuk larutan garam jenuh pada suhu $30^{\circ} \mathrm{C}$

\begin{tabular}{ccc}
\hline $\begin{array}{c}\text { Jenis larutan } \\
\text { garam }\end{array}$ & $\begin{array}{c}\text { Aktivitas air } \\
\left(\mathrm{A}_{\mathrm{w}}\right)\end{array}$ & ERH (\%) \\
\hline $\mathrm{MgCl}_{2}$ & 0,324 & 32,4 \\
$\mathrm{~K}_{2} \mathrm{CO}_{3}$ & 0,432 & 43,2 \\
$\mathrm{NaCl}$ & 0,749 & 74,9 \\
$\mathrm{KCl}$ & 0,836 & 83,6 \\
$\mathrm{KNO}_{3}$ & 0,923 & 92,3 \\
\hline
\end{tabular}

Sumber: Bell dan Labuza(2000)

Sampel gula kelapa kristal sebanyak 2-5 g dimasukkan dalam cawan keramik yang telah diketahui beratnya. Cawan berisi sampel tersebut dimasukkan ke dalam desikator modifikasi toples yang berisi larutan garam jenuh, dengan posisi dari bawah ke atas berturut-turut yaitu larutan garam, penyangga, dan cawan beserta isinya, serta terdapat jarak antara larutan garam dan penyangga.

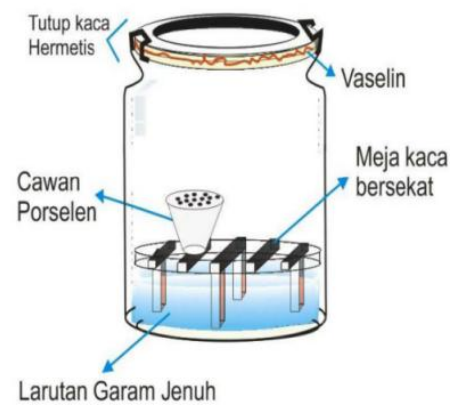

Gambar 1. Sketsa desikator (modifikasi Hutasoit N, 2009)

Desikator disimpan pada suhu ruang dan sampel ditimbang secara periodik tiap 24 jam hingga mencapai bobot yang setimbang atau berjamur. Bobot yang setimbang ditandai dengan selisih 3 penimbangan berturut-turut $\leq 2 \mathrm{mg}$ untuk $\mathrm{RH}$ di bawah $90 \%$ dan $\leq 10 \mathrm{mg}$ untuk $\mathrm{RH}$ di atas $90 \%$. Sampel yang telah mencapai berat konstan kemudian diukur kadar airnya dengan 
metode oven (Sudarmadji et al.,1997) dan dinyatakan dalam $\mathrm{g} \mathrm{H}_{2} \mathrm{O} / \mathrm{g}$ padatan.

\section{Penentuan Kurva dan Model Persamaan sorpsi Isotermis.}

Penentuan kurva sorpsi isotermis dibuat dengan cara memplotkan kadar air kesetimbangan hasil percobaan dengan nilai kelembaban relatif (RH) atau aktifitas air (aw) dan dimasukkan dalam model persamaan sorpsi isotermis. Model yang dipake yaitu: model Guggenheim- Anderson-de Boer (GAB), Hasley, Handerson, Caurie, Oswin dan Chen Clayton (Bell dan Labuza, 2000).

\section{Uji Ketepatan Model (Walpole, 1990)}

Uji ketepatan persamaan sorpsi isotermis dilakukan untuk mengetahui ketepatan dari beberapa model persamaan sorpsi isotermis yang terpilih sehingga memperoleh kurva sorpsi isotermis dengan menggunakan perhitungan Mean Relative Determination (MRD) (Walpole, 1990).

$$
\mathrm{MRD}=\frac{100}{\mathrm{n}}=\sum_{i=1}^{n}\left|\frac{\mathrm{Mi}-\mathrm{Mpi}}{\mathrm{Mi}}\right|
$$

Keterangan:

$\mathrm{Mi}$ : Kadar air percobaan

Mpi : Kadar air hasil perhitungan

n : Jumlah data

Nilai MRD <5 maka model sorpsi isotermis tersebut dapat mengGambarkan keadaan yang sebenarnya atau sangat tepat. Jika $5<$ MRD $<10$ maka model tersebut agak tepat mengGambarkan keadaan sebenarnya dan jika MRD>10 maka model tersebut tidak tepat mengGambarkan kondisi sebenarnya. Pemilihan uji ketepatan persamaan sorpsi isotermis dengan menggunakan nilai MRD karena nilai MRD mampu memberikan nilai yang akurat dalam menggambarkan fenomena sorpsi isotermis jika dibandingkan dengan berhimpitnya kurva sorpsi isotermis dari model persamaan dan hasil percobaan.

\section{Penentuan Nilai Slope (b) Kurva Sorpsi Isotermis (Labuza, 1982)}

Nilai slope (b) kurva sorpsi isotermis ditentukan pada daerah linear (Arpah, 2001). Daerah linear tersebut diambil antara daerah kadar air awal dan kadar air kritis (Labuza 1982). Titik-titik hubungan antara aktifitas air dan kadar air kesetimbangan memiliki persamaan linier $y=a+b x$. Nilai $b$ persamaan tersebut merupakan slope kurva sorpsi isotermis.Nilai $\mathrm{b}$ ditentukan dari model persamaan terpilih (kemiringan kurva sorpsi isotermis yang diasumsikan linier antara Mo dan Mc) untuk dimasukkan dalam rumus umur simpan Labuza.

\section{Penentuan Permeabilitas Kemasan} (ASTM F 1249-2006)

Penentuan permeabilitas kemasan dilakukan dengan menggunakan alat Permatran Mocon sehingga diperoleh nilai WVTR. Untuk nilai $k / x$ menggunakan persamaan :

$$
\mathrm{k} / \mathrm{x}=\frac{W V T R}{(\mathrm{Po})(\mathrm{RH})}
$$

Keterangan:

$\mathrm{k} / \mathrm{x} \quad$ : konstanta permeabilitas uap air kemasan $\left(\mathrm{g} / \mathrm{m}^{2}\right.$.hari.mmHg)

WVTR : laju perpindahan uap air melalui kemasan $\left(\mathrm{g} / \mathrm{m}^{2} /\right.$ hari/RH)

Po : tekanan uap air di lingkungan (mmHg)

Nilai WVTR juga dapat ditentukan dengan memasukan sampel gula kelapa kristal kedalam cawan kemudian permukaan atas cawan ditutup dengan menggunakan plastik polietilen (PE) kemudian diikat menggunakan karet hingga tidak ada udara yang masuk. Pengamatan dilakukan tiap hari dengan cara menimbangnya sampai mendapatkan lima titik kemudian dibuat grafik. Hasil pengamatan dibuat grafik dan Tabel kemudian dicari nilai WVTR (Anandito et al., 2010).

\section{Penentuan Bobot Padatan Per Kemasan} (Ws) dan Luas Kemasan (A)

Bobot produk awal (Wo) dalam satu kemasan ditimbang dan dikoreksi kadar air awalnya (Mo) yang merupakan berat padatan per kemasan (Ws). Luas kemasan (A) yang diukur adalah luas total dari kedua muka dari kemasan primer yang digunakan untuk mengemas gula kelapa kristal.

\section{HASIL DAN PEMBAHASAN}

\section{A. Kadar air awal dan kadar air kritis}

Kadar air awal (Mo) gula kelapa kristal merupakan data yang penting yang perlu diketahui dalam pendugaan umur simpan 
model kadar air kritis. Kadar air awal gula kelapa kristal adalah $0,06 \mathrm{~g} \mathrm{H}_{2} \mathrm{O} / \mathrm{g}$ padatan. Berdasarkan kadar air tersebut berat padatan perkemasan untuk gula kelapa kristal kemasan alumunium foil adalah $169,5 \mathrm{~g}$ sedangkan kemasan Polietilen adalah 141,84g. Kadar air kritis juga perlu diketahu sebagai batas penerimaan produk. Kadar air kritis ditentukan berdasarkan atribut sensori yang terpenting dari gula kelapa kristal, yaitu pada saat hilangnya tekstur keringan. Tabel 2 menyajikan data perubahan kadar air dan skor kekeringan selama periode pengamatan untuk gula kelapa kristal.

Tabel 2. Perubahan skor kekeringan dan kadar air gula kelapa kristal.

\begin{tabular}{ccc}
\hline $\begin{array}{c}\text { Waktu } \\
\text { (Hari) }\end{array}$ & Skorkekeringan & $\begin{array}{c}\text { Kadarair }\left(\mathrm{gH}_{2} \mathrm{O} / \mathrm{g}\right. \\
\text { Padatan })\end{array}$ \\
\hline 0 & 6,07 & 6,78 \\
1 & 4,93 & 8,45 \\
2 & 4,20 & 9,65 \\
3 & 3,53 & 10,38 \\
4 & 2,93 & 12,38 \\
\hline
\end{tabular}

Rentang skor kekeringan : (1) sangat tidak kering - (7) sangatkering

Data tersebut diplotkan dalam bentuk grafik hubungan antara kadar air (sumbu $\mathrm{x}$ ) dengan rata-rata skor kekeringan (sumbu y) (Gambar 1).

Persamaan yang diperoleh untuk gula kelapa kristal adalah y $=-0,5741 x+9,8042$ dengan nilai $R=0,9692$. Berdasarkan persamaan regresi tersebut, diperoleh nilai kadar air kritis (Mc) untuk gula kelapa kristal adalah $0,0823 \mathrm{~g} \mathrm{H}_{2} \mathrm{O} / \mathrm{g}$ padatan.

\section{B. Kurva isotermsorpsi air}

Pengukuran kadar air kesetimbangan (Me) pada berbagai RH garam dilakukan untuk mendapatkan kurva isoterm sorpsi air. Selama penyimpanan, gula kelapa kristal menunjukan kenaikan bobot. Hal ini menunjukkan bahwa gula mengalami proses adsorpsi uap air dari lingkungan karena $\mathrm{a}_{\mathrm{w}}$ lebih rendah dari RH lingkungannya.

Selama penyimpanan dalam berbagai kondisi $\mathrm{RH}$ terjadi interaksi antara produk dengan lingkungannya. Uap air berpindah dari lingkungan produk sampai tercapai kondisi kesetimbangan. Perpindahan uap air ini terjadi sebagai akibat perbedaan $\mathrm{RH}$ lingkungan dan produk, dimana uap air berpindah dari $\mathrm{RH}$ tinggi ke $\mathrm{RH}$ rendah. Tercapainya kondisi kesetimbangan antara contoh dan lingkungan ditandai oleh bobot yang konstan. Peningkatan atau penurunan bobot contoh selama penyimpanan menunjukkan fenomena hidratasi (deMan, 1989). Kadar air kesetimbangan yang diperoleh dari percobaan tersebut diplotkan dengan nilai $\mathrm{a}_{\mathrm{w}}$ atau RH lingkungannya, sehingga diperoleh kurva isoterm sorpsi air (Gambar 3). Untuk memperoleh kurva yang mulus, maka data kadar air kesetimbangan pada $a_{w}$ tertentu dimasukkan ke dalam (6) model (Tabel 3 untuk gula kelapa kristal).

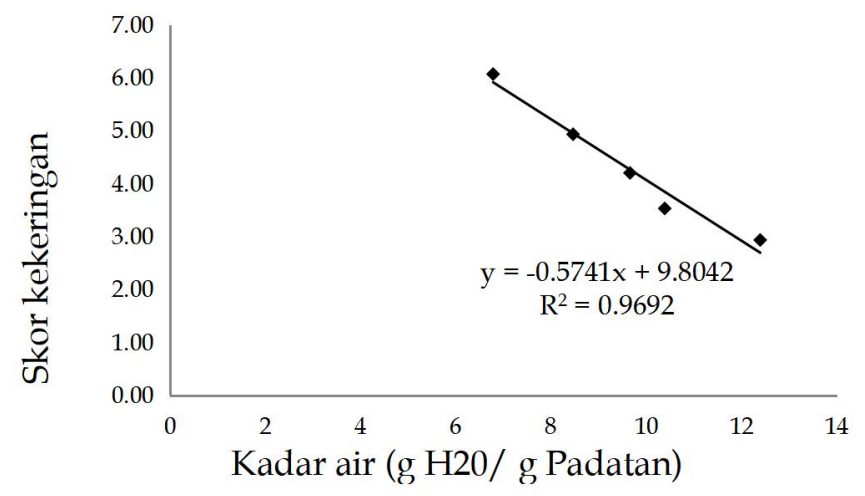

Gambar1.Hubungan skor kekeringan dengan kadar air gula kelapa kristal 


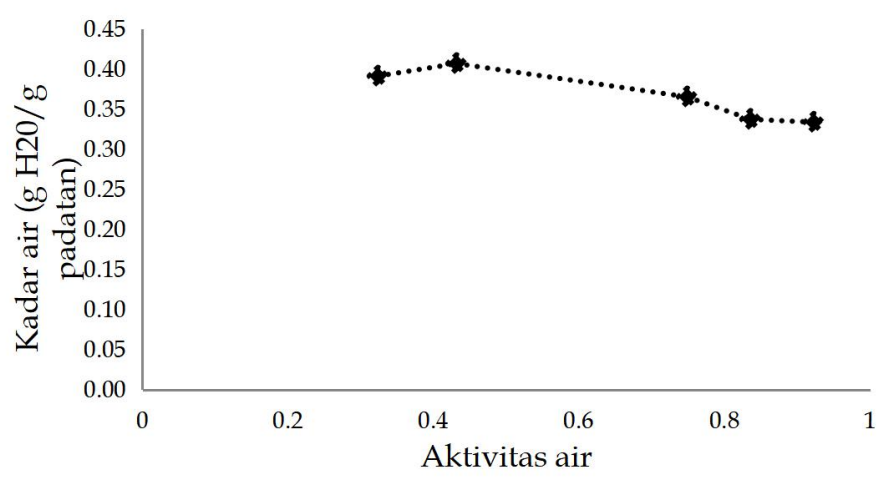

Gambar 2. Kurva sorpsiisotermis gula kelapa kristal

Tabel 3. Model persamaan kurva sorpsiisotermis gula kelapa kristal

\begin{tabular}{lll}
\hline Model & Persamaan & MRD \\
\hline Hasley & $\log [\ln (1 / \mathrm{aw})]=-1,7218-2,8369 \operatorname{logMe}$ & 30,06 \\
Chenclayton & $\ln [\ln (1 / \mathrm{aw})]=1,8689-8,1234 \mathrm{Me}$ & 28,14 \\
Henderson & $\log [\ln (1 /(1-\mathrm{aw}))]=0,4366+0,9288 \log \mathrm{Me}$ & 73,50 \\
Caurie & $\operatorname{lnMe}=-1,0252+0,028 \mathrm{aw}$ & 7,03 \\
Oswin & $\operatorname{lnMe}=-1,1071-0,0122 \ln [\mathrm{aw} /(1-\mathrm{aw})]$ & 8,79 \\
GAB & $\mathrm{Me}=4,0877 \mathrm{aw} /(1-0,1898 \mathrm{aw})\left(1-0,1898 \mathrm{aw}-8,8938^{\star} 0,1898 \mathrm{aw}\right.$ & 443,04 \\
\hline
\end{tabular}

Tabel di atas menunjukan nilai MRD yang diperoleh dari masing-masing persamaan. Model persamaan yang dapat menggambarkan kurva sorpsi isotermis yang paling tepat untuk gula kelapa kristal adalah model Caurie yaitu 7,03. Meskipun nilai MRD tersebut lebih dari 5 akan tetapi model ini mengGambarkan kurva sorpsi isotermis yang tepat. Hal ini sesuai dengan pernyataan Tarigan et al. (2006) bahwa semakin kecil nilai MRD maka semakin tepat pula model tersebut dalam mengGambarkan fenomena sorpsi isotermis yang terjadi.

Nilai kemiringan kurva isoterm sorpsi air ditentukan pada daerah linier dari kurva isoterm sorpsi air (Arpah, 2001). Menurut Labuza (1982), daerah linier untuk menentukan kemiringan (slope) kurva sorpsi isotermis diambil pada daerah yang melewati Mo (kadar air awal) pada model kurva isoterm sorpsi air. Berdasarkan grafik kurva isoterm sorpsi air (Gambar 3), maka nilai kemiringan kurva isoterm sorpsi air (b) untuk gula kelapa kristal adalah 0,0102. Agoes (2010) menyebutkan bahwa pendekatan kurva sorpsi isotermis merupakan metode yang lebih tepat. Pendekatan kadar air kritis termodifikasi digunakan untuk produk yang memiliki kelarutan tinggi seperti produk dengan kadar sukrosa tinggi (Bell et al., 2000).

Permeabilitas uap air kemasan $(\mathrm{k} / \mathrm{x})$ adalah kecepatan atau laju transmisi uap air melalui suatu unit luasan bahan yang permukaannya rata dengan ketebalan tertentu sebagai akibat perbedaan unit tekanan uap air antara permukaan produk pada kondisi suhu dan RH tertentu. Pertiwi et al. (2017) melakukan penelitian tentang umur simpan cookies nanas, meyebutkan bahwa jenis ke-masan memberikan pengaruh yang nyata terhadap kadar air, tekstur cookies nenas yang disimpan pada suhu $15^{\circ} \mathrm{C}$. Kemasan PE dapat meningkatkan umur simpan makanan, me-ngurangi pembusukan dan meningkatkan ketersediaan produk makanan yang berbeda kepada masyarakat umum (Krohn, 1997).

\section{Penentuan umur simpan gula kelapa kristal}

Batas mutu minimum adalah nilai mutu dimana produk mulai ditolak oleh konsumen (Hough et al., 2006). Parameter kritis gula kristal ditentukan oleh teksturnya yang dipengaruhi oleh kadar air. Kenaikan kadar air mengakibatkan kondisi gula kristal menjadi berubah dari remah berbutir menjadi butiran-butiran yang saling merekat dan menggumpal. Cara optimal memperbaiki struktur gula yang meleleh adalah dengan cara mengolah menjadi gula granular, yakni melalui peleburan kembali gula cetak dengan penambahan air menjadi larutan gula. Penambahan gula pasir dan pembibitan ternya- 
ta berpengaruh pada rendemen, total gula, sukrosa, dan tingkat kesukaan warna, rasa dan aroma, tetapi menurunkan kadar air, gula reduksi, indeks pen-coklatan dan tingkat aroma (Joseph et al., 2012). Kurniawan et al. (2018), menyebutkan bahwa Hasil pendugaan umur simpan gula kristal menggunakan metode arhenius diperoleh bahwa gula kristal yang disimpan pada suhu $15^{\circ} \mathrm{C}$ RH $77 \%$ memiliki umur simpan yang lebih lama yaitu 160 hari, sedangkan umur simpan gula kristal paling pendek terjadi pada kondisi penyimpanan suhu $35^{\circ} \mathrm{C} \mathrm{RH} 98 \%$. Nilai parameter dan umur simpan gula kelapa kristal ditunjukkan pada Tabel 4 dan 5 .

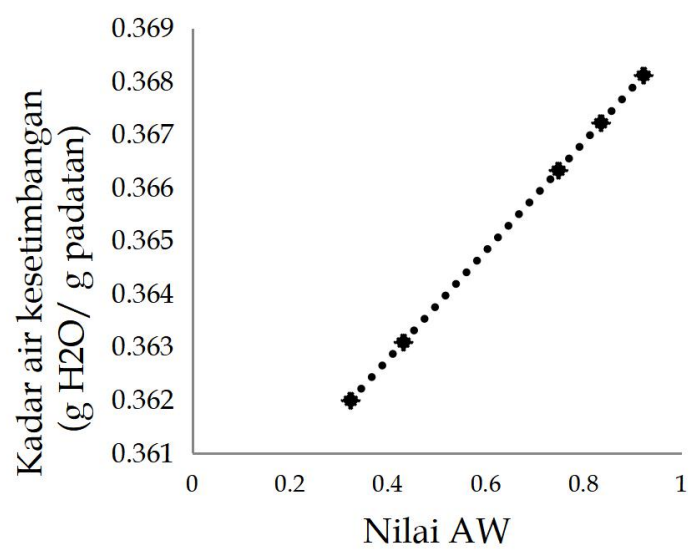

Gambar 3. Penentuan slope kurva sorpsi-isotermis model caurie gula kelapa kristal

Tabel 4. Parameter dan umur simpanuntuk jenis kemasan polietilen

\begin{tabular}{lc}
\hline \multicolumn{1}{c}{ Parameter } & Nilai \\
\hline Kadar air kesetim bangan (Me, g/H2O/g padatan) & 0,3653 \\
Kadar air awal produk (Mo, g/ H2O/g padatan) & 0,0579 \\
Kadar air kritis (Mc, g/ H2O/g padatan) & 0,0824 \\
Kemiringan/Slope & 0,0102 \\
Konstanta permeabilitas kemasan (k/, $\mathrm{g} / \mathrm{m} 2 . h a r i . m m H g)$ & 0,0004 \\
Luas permukaan kemasan (A, $\left.{ }^{2}\right)$ & 0,0348 \\
Berat kering produk dlm Kemasan (Ws, g padatan) & 169,500 \\
Tekanan uap jenuh (Po, mmHg) & 30,3398 \\
Waktu perkiraan umur simpan (t, hari) & 340,154 \\
\hline Waktu perkiraan umur simpan (t, bulan) & $\mathbf{1 1 , 3 3 8}$ \\
\hline
\end{tabular}

Tabel 5. Parameter dan umur simpanuntuk jenis kemasan alumunium foil

\begin{tabular}{lc}
\hline \multicolumn{1}{c}{ Parameter } & Nilai \\
\hline Kadar air kesetimbangan (Me, g/H2O/g padatan) & 0,3653 \\
Kadar air a wal produk (Mo, g/H2O/g padatan) & 0,0579 \\
Kadar air kritis (Mc, g/H2O/g padatan) & 0,0824 \\
Kemiringan/Slope & 0,0102 \\
Konstanta permeabilitas kemasan (k/x, g/m2.hari.mmHg) & 0,0002 \\
Luas permukaan kemasan (A,m $\left.{ }^{2}\right)$ & 0,0368 \\
Berat kering produk dlm Kemasan (Ws, g padatan) & 141,844 \\
Tekanan uap jenuh (Po, mmHg) & 30,3398 \\
Waktu perkiraan umur simpan & \\
(t, hari) & 537,661 \\
\hline Waktu perkiraan umur simpan (t, bulan) & $\mathbf{1 7 , 9 2 2}$ \\
\hline
\end{tabular}




\section{SIMPULAN}

Awal kerusakan gula kelapa kristas ditandai dengan mulai tidak diterimanya gula oleh konsumen karena kekeringannya yang tercapai pada kadar air kritis $0,0824 \mathrm{~g} \mathrm{H} 2 \mathrm{O} / \mathrm{g}$ padatan. Berdasarkan pendekatan kadar air kritis, maka diketahui bahwa umur simpan gula kelapa kristal yang disimpan pada $\mathrm{RH}$ $60 \%$ dan dikemas menggunakan polietilen adalah 18 bulan sedangkan yang dikemas menggunakan alumanium foil selama 11 bulan. Jadi yang cocok untuk kemasan gula kristal yang baik pada penelitian ini adalah Polietilen.

\section{UCAPAN TERIMA KASIH}

Terimakasih kepada Lembaga Peneitian dan Pengabdian Masyarakat (LPPM) Universitas Jenderal Soedirman atas dukungan dana dalam Penelitian Skim Penelitian Dosen Pemula.

\section{DAFTAR PUSTAKA}

Agoes -MJ, Mala -NM, Hutasoit N. 2010. Penentuan umur simpan fish snack (produk ekstrusi) menggunakan metode akselerasi dengan pendekatan kadar air kritis dan metode konvensional. Jurnal Sumber Daya Perair. 4(1): 1-6. http://journal.ubb.ac.id/index.php/aku atik/article/view/407

Anandito, -R. Baskara -K, Basito, Hatmiyarni T.H. 2010. Kinetika Penurunan Kadar Vanilin Selama Penyimpanan Polong Panili Kering pada Berbagai Kemasan Plastik. AGROINTEK, Vol. 4, No. 2: 146-147. https://journal.trunojoyo.ac.id/agrointe k/article/view/1368

AOAC. 1995. Official Methods of Analysis. Washington: Association of Official Analytical Chemists

Arpah, -M. 2001. Buku dan Monograf Penentuan Kadaluwarsa Produk Pangan. Program Pascasarjana, Institut Pertanian Bogor. Bogor.
Bell,-L.N. T.P. Labuza. 2000. Moisture Sorption Practical Aspects of Isotherm Measurement and Use. 2nd ed. The American Association of Cereal Chemist, Inc.

deMan, -M.J. 1989. Kimia Makanan. Penerjemah : K.Padmawinata. ITB-Press, Bandung

Hough, -G, Garitta, -L, Gomes, -G. 2006. Sensory shelf life predictions by survival analysis accelerated storage models. Food Qual Prefer. 17(6), 468-73. https://doi.org/10.1016/j.foodqual.200 5.05.009

Hutasoit, -N. 2009. Penentuan umur simpan fish snack (produk ekstrusi) menggunakan metode akselerasi dengan pendekatan kadar air kritis dan metode konvensional. Skripsi. Institut Pertanian Bogor. Bogor

Joseph -G., Layuk -P. 2012. Pengolahan gula kristal dari aren. Buletin Palma. 13(1), 60-65. http:// ejurnal.litbang.pertanian.go. id/index.php/palma/article/view/559 6

Krohn, James. 1997. Factors Affecting The Permeability Of Pe Blown Films. Cincinnati Technology Center, 1(2), 1-6. https://doi.org/10.1177/8756087997013 00408

Kurniawan -H, Bintoro -N, Nugroho -W.K..J. 2018. Pendugaan umur simpan gula kristal dalam kemasan dengan pendekatan arrhenius. Jurnal Ilmu Rekayasa Pertanian Dan Biosistem, 6(1), 93-9. https://doi.org/10.29303/jrpb.v6il.68

Labuza, T-.P. M.K. Schmidl. 1985. Accelerated shelf life testing of foods. Food Technology. 39(9): 57-62

Sudarmadji, -S., B. Haryono, dan Suhardi. 1997. Prosedur Analisa Untuk Bahan Makanan dan Pertanian. Liberty. Yogyakarta.

Syarief, -R,S. Santausa -B.ST. Isyana. 1989. Teknologi Pengemasan Pangan. Laboratorium Rekayasa Pangan. Pusat Antar Universitas Pangan dan Gizi. Institut Pertanian Bogor.

Walpole, -R.E, 1990, Pengantar Statistika, Edisi ketiga, Terjemahan Gramedia Pustaka Utama, Jakarta 